\title{
Experimental Organism Basal Cell Adenoma
}

National Cancer Institute

\section{Source}

National Cancer Institute. Experimental Organism Basal Cell Adenoma. NCI Thesaurus.

Code C111198.

A benign epithelial neoplasm with a uniform, monomorphic appearance that is dominated by basal cells. (SEND) 